Article

\title{
Effect of Preparation Conditions on Structure and Activity of Sodium-Impregnated Oyster Shell Catalysts for Transesterification
}

\author{
Han Jin ${ }^{1}$, Praveen Kolar ${ }^{1, *}$, Steven W. Peretti ${ }^{2}$, Jason A. Osborne ${ }^{3}$ and Jay J. Cheng ${ }^{1}$ \\ 1 Department of Biological and Agricultural Engineering, North Carolina State University, \\ Raleigh, NC 27695, USA; hjin4@ncsu.edu (H.J.); jcheng3@ncsu.edu (J.J.C.) \\ 2 Department of Chemical \& Biomolecular Engineering, North Carolina State University, \\ Raleigh, NC 27695, USA; peretti@ncsu.edu \\ 3 Department of Statistics, North Carolina State University, Raleigh, NC 27695, USA; jaosborn@ncsu.edu \\ * Correspondence: pkolar@ncsu.edu; Tel.: +1-919-513-9797
}

Received: 21 May 2018; Accepted: 21 June 2018; Published: 26 June 2018

\begin{abstract}
The catalyst preparation technique plays a significant role in its activity and durability. The present research investigated sodium hydroxide and sodium chloride as the precursor chemicals for impregnation on waste oyster shells that were tested as heterogeneous base catalysts for transesterification of soybean oil. Effects of precursor concentration and calcination temperature on the surface structure and the activity of the catalysts were studied via the one-factor-at-a-time method. The optimal impregnation concentrations of sodium hydroxide and sodium chloride were determined to be $6 \mathrm{~mol} / \mathrm{L}$ and $2.43 \mathrm{~mol} / \mathrm{L}$, respectively. The optimal calcination temperature was determined to be $800{ }^{\circ} \mathrm{C}$ for both sodium hydroxide and sodium chloride-impregnated catalysts. Analyses of the catalysts via X-ray Diffraction and X-ray photoelectron spectroscopy indicated that different active species were formed on the surface depending on the calcination temperature. Results obtained from this study could be used to fine-tune the procedure for the synthesis of transesterification catalysts from aquatic animal shells.
\end{abstract}

Keywords: oyster shell; impregnation; transesterification; fatty acid methyl ester; biodiesel

\section{Introduction}

Solid base catalysts have been extensively studied for their catalytic performance in transesterification reactions [1]. $\mathrm{CaO}$ is one of such solid base catalysts capable of transesterification of various oils to fatty acid methyl esters (FAME). However, its activity was still found to be lower than that of $\mathrm{NaOH}$ [2]. Hence, to increase the catalytic activity of $\mathrm{CaO}$, wet impregnation methods have been employed to modify the surface of $\mathrm{CaO}$ to generate more active sites. Doped could react with the oxygen present in $\mathrm{CaO}$ to produce defect sites on the surface, which served as the enhanced basic sites for transesterification reactions [3-8]. Watkins et al., impregnated $\mathrm{CaO}$ with a series of $\mathrm{LiNO}_{3}$ solutions in the range of 1-20 wt. \% [4]. Despite showing a continuous drop in specific surface area (with increasing Li content), all Li-impregnated $\mathrm{CaO}$ catalysts that were tested exhibited increased basic strengths when compared to $\mathrm{CaO}$. The transesterification results indicated that the initial reaction rate increased with the increased Li content and reached a maximum when Li content reached $1.23 \mathrm{wt}$. \%. Further, the characterization study indicated that the doped $\mathrm{CaO}$ helped the formation of surface $\mathrm{OH}^{-}$ which enhanced the catalytic activity. However, it was noted that the high concentration of $\mathrm{LiNO}_{3}$ may have covered the surface $\mathrm{OH}^{-}$group, and thus may have lowered the catalytic activity.

In addition to the alkali metal oxides and hydroxide groups generated from the impregnation-calcination method, calcium and halogen have also been identified by many research 
groups as active species. Mar and Somsook used $\mathrm{KCl}$ to modify the surface of $\mathrm{CaO}$ by the wet impregnation method under microwave irradiation followed by calcination [5]. When the catalyst was characterized, $\mathrm{KCaCl}_{3}$ phase was detected on the surface, which contributed to the increased FAME yield during transesterification of soybean oil using methanol. A similar observation has been reported by Wen et al., in which $\mathrm{KF}$ was tested as an impregnating agent on $\mathrm{CaO}$ [6]. A new $\mathrm{KCaF}_{3}$ phase was observed on the surface of the catalysts and the increased catalytic activity was attributed to the higher $\mathrm{H}^{+}$affinity for $\mathrm{F}^{-}$. Similarly, Liu et al., synthesized $\mathrm{CsF} / \mathrm{CaO}$ catalyst by mixing CsF solution with $\mathrm{Ca}(\mathrm{OH})_{2}$ solution followed by calcination [7]. The catalyst exhibited excellent activity in transesterification reaction in which about $98 \%$ FAME yield was obtained in $1 \mathrm{~h}$ under optimal reaction conditions. The highly improved activity was plausibly attributed to the formation of $\mathrm{CsCaF}_{3}$ on the surface. Interestingly, somewhat different results were obtained when $\mathrm{KBr}$ was impregnated on $\mathrm{CaO}$ [8]. XRD analyses did not detect the presence of $\mathrm{KCaBr}_{3}$ phase on the surface, perhaps because of the larger radius of $\mathrm{Br}$ that may not have allowed the formation of $\mathrm{KCaBr}_{3}$ on the surface.

Besides alkaline metals, other chemical agents have also been tested for their ability to enhance the catalytic activity of $\mathrm{CaO}$. Yan et al., synthesized a solid catalyst, $\mathrm{Ca}_{3} \mathrm{La}_{1}$, by mixing $\mathrm{La}\left(\mathrm{NO}_{3}\right)_{3}$ solution with $\mathrm{Ca}(\mathrm{Ac})_{2}$ solution followed by addition of ethanol and bubbling the solution with $\mathrm{CO}_{2}$. The resultant precipitate was calcined to obtain $\mathrm{Ca}_{3} \mathrm{La}_{1}$ [9]. The as-synthesized catalyst consisted of $\mathrm{Ca}(\mathrm{OH})_{2}$ as the major phase on the surface, and the initial reaction rate and FAME yield after $2 \mathrm{~h}$ using $\mathrm{Ca}_{3} \mathrm{La}_{1}$ were similar to the $\mathrm{NaOH}$-catalyzed transesterification, indicating $\mathrm{Ca}_{3} \mathrm{La}_{1}$ as a potential substitute for transesterification reactions. Kuar and Ali synthesized $\mathrm{Zr} / \mathrm{CaO}$ catalyst using wet impregnation by mixing $\mathrm{CaO}$ with $\mathrm{ZrOCl}_{2} \cdot 8 \mathrm{H}_{2} \mathrm{O}$ solution followed by calcination [10]. The $15 \mathrm{wt}$ \% $\mathrm{Zr} / \mathrm{CaO}$ calcined at $700{ }^{\circ} \mathrm{C}$ exhibited highest reaction rate in transesterifying jatropha curcas oil. The authors attributed the activity of the catalyst to the relatively lower ratio of tetragonal to monoclinic $\mathrm{ZrO}_{2}$ on the surface and decreased crystallite size.

Recently, waste natural shells have attracted attention, since they could serve as the economical precursors for $\mathrm{CaO}$. Various natural shells have been tested for catalyzing transesterification reactions. For example, Wei et al. used waste eggshell as the precursor for the catalyst and reported a FAME yield of over $95 \%$ during transesterification of soybean oil for a methanol to oil ratio (MR) of 9 , and catalyst loading (CL) of $3 \%$, at $65{ }^{\circ} \mathrm{C}$ within $3 \mathrm{~h}$ [11]. Rezaei et al., employed calcined mussel shell to catalyze transesterification of soybean oil and observed a $94.1 \%$ FAME yield at MR of $24, \mathrm{CL}$ of $12 \%$ at $60{ }^{\circ} \mathrm{C}$ in $8 \mathrm{~h} \mathrm{[12].} \mathrm{Similarly,} \mathrm{calcined} \mathrm{capiz} \mathrm{shell} \mathrm{(Amusium} \mathrm{cristatum)} \mathrm{was} \mathrm{tested} \mathrm{as} \mathrm{a} \mathrm{catalyst} \mathrm{for} \mathrm{converting}$ palm oil into FAME by Suryaputra et al., who reported a FAME yield of 93\% using a MR of 8 and CL of $3 \%$ [13]. However, the natural shell-derived $\mathrm{CaO}$ exhibited relatively lower activity compared to commercial $\mathrm{CaO}$ and $\mathrm{NaOH}$ [11-13]. Thus, to improve the activity, natural shells may be impregnated with chemicals. Jaraim et al., improved the activity of calcined oyster shell by impregnating $1 \mathrm{mmol} / \mathrm{g}$ of KI [14]. Additionally, preparation conditions could be manipulated to enhance the activity of shells. Wei et al. investigated the effect of calcination temperature and reported that eggshells calcined at $800{ }^{\circ} \mathrm{C}$ or above exhibited high activity due to the formation of $\mathrm{CaO}$ [11]. Similar results were observed by Rezaeti et al., wherein the minimum calcination temperature was observed to be $950{ }^{\circ} \mathrm{C}$ for the formation of $\mathrm{CaO}$ [12].

In our recent research, we reported an active base catalyst that was prepared by impregnating $\mathrm{NaOH}$ on oyster shell followed by calcination [15]. Our results indicated that impregnation of $\mathrm{NaOH}$ on oyster shell increased the FAME yield from $71 \%$ ( $3 \mathrm{~h}$ reaction time) (control) to $87 \%$ ( $1 \mathrm{~h}$ reaction time). In addition, the analysis of the surface of the catalyst revealed that impregnation of $\mathrm{NaOH}$ followed by calcination resulted in the formation of sodium peroxide species that significantly enhanced the activity of the calcined oyster shells [16].

Further, the activity of the oyster shell catalyst directly depends on the preparation conditions, especially precursor loading, and calcination temperature. In other words, right amounts of precursor when calcined at right temperature will maximize the formation of active sites on the surface that can significantly enhance transesterification reactions. However, to our knowledge, there is limited 
information on how the activity of oyster shell catalyst is influenced by preparation conditions. By elucidating how calcination temperature and impregnation conditions affect the catalyst activity will not only improve catalyst synthesis processes but also allow us to predict the performance of the catalyst. Hence, the goal of this research is to systematically investigate how the catalyst preparation conditions (precursor type, precursor concentration, calcination temperature) influence the structure and subsequent activity of the catalyst.

\section{Results and Discussion}

\subsection{Effects of the Precursor Type and Concentration}

Figure 1 summarized the effects of precursor type and concentration. For both precursors, the calcined oyster shell (COS) was used as a control for comparison purposes. When a concentration of $2 \mathrm{~mol} / \mathrm{L}$ was used for impregnation, there were no significant differences between the FAME yields obtained from control (COS) and $\mathrm{NaCl} /$ shell and $\mathrm{NaOH} /$ shell catalysts suggesting that no catalytically active sites were formed on the surface of the oyster shells at lower precursor concentrations. When the precursor concentrations were increased, significant differences were observed. For $\mathrm{NaOH} /$ shell experiments, FAME yields increased from $8 \%$ to $83 \%$ when precursor $(\mathrm{NaOH})$ concentration increased from $2 \mathrm{~mol} / \mathrm{L}$ to $6 \mathrm{~mol} / \mathrm{L}$.

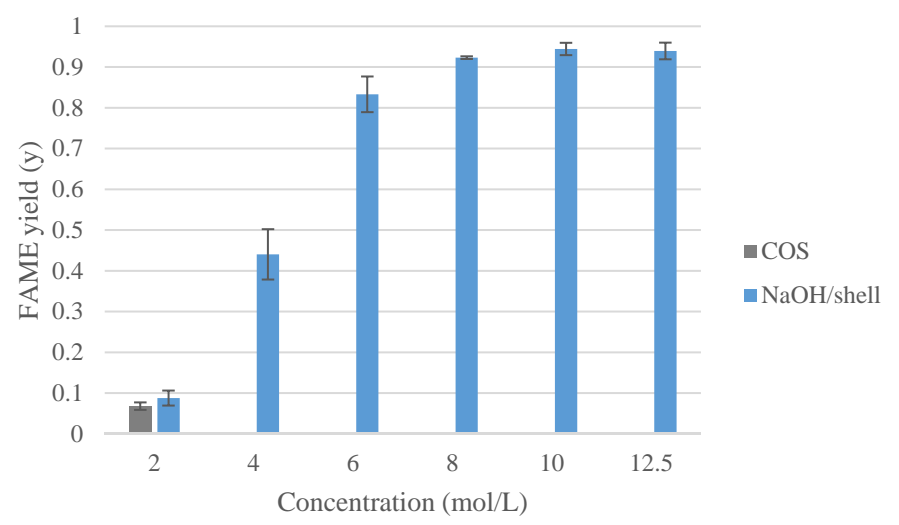

(a)

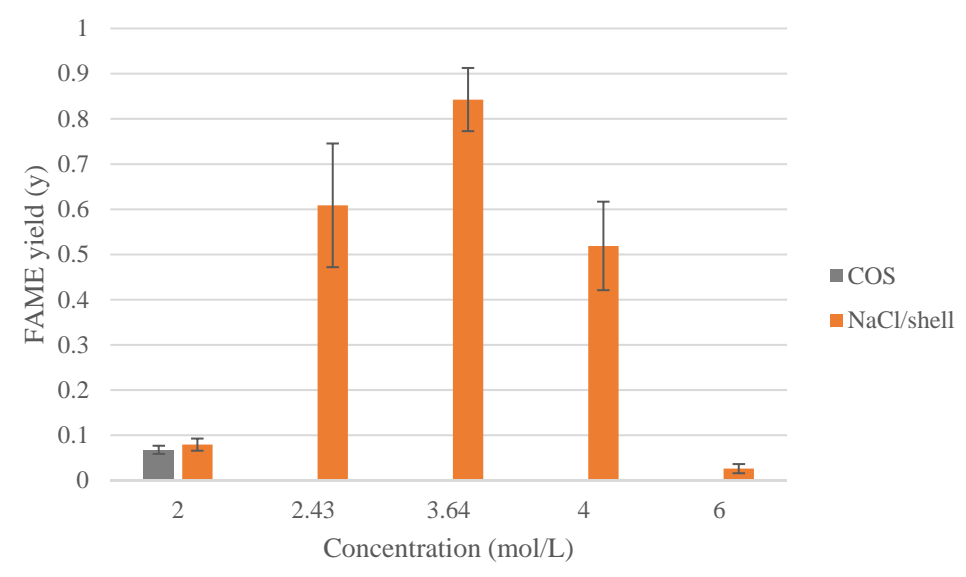

(b)

Figure 1. The FAME yield of the transesterification reaction catalyzed by various concentrations of $\mathrm{NaOH}$ (a) and $\mathrm{NaCl}$ (b) impregnated calcined oyster shell. Transesterification conditions: temperature $=62{ }^{\circ} \mathrm{C}$; stirring rate $=800 \mathrm{rpm} ; \mathrm{MR}=12 ; \mathrm{CL}=10 \%$. 
However, for precursor concentrations beyond, $6 \mathrm{~mol} / \mathrm{L}$, FAME yields appeared to be similar (FAME yield between $83 \%$ and $94 \%$ ) (Figure 1a). Our results agree with those reported by de Luna et al. who investigated the activity of $\mathrm{NaOH}$ impregnated pumice stone as catalysts for transesterification of soybean oil [17]. The authors reported a significant increase in fractional conversion of soybean oil when the precursor concentration was increased due to the incorporation of sodium ions within pumice stone matrix. The results obtained from $\mathrm{NaCl} /$ shell exhibited a different trend. As shown in Figure $1 \mathrm{~b}$, the FAME yield increased (from $8 \%$ to $84 \%$ ) when the precursor concentration was increased from $2 \mathrm{~mol} / \mathrm{L}$ to $3.64 \mathrm{~mol} / \mathrm{L}$ and started decreasing when the precursor concentration was further increased beyond $3.64 \mathrm{~mol} / \mathrm{L}$, suggesting that presence of excess precursor may inhibit catalytic activity as shown in Figure 1. However, no significant differences in FAME yields were found between precursor loadings of 2.43 and $3.64 \mathrm{~mol} / \mathrm{L}$. Hence, precursor concentrations of $6 \mathrm{~mol} / \mathrm{L}$ (for $\mathrm{NaOH}$ ) and $2.43 \mathrm{~mol} / \mathrm{L}$ (for $\mathrm{NaCl}$ ) were selected for subsequent studies to investigate the effect of calcination of catalyst activity.

\subsection{Effect of Calcination Temperature}

The effects of calcination temperature are summarized in Figure 2. For experiments with $\mathrm{NaOH} /$ shell, calcination temperature $\left(400,600,800\right.$, and $\left.1000{ }^{\circ} \mathrm{C}\right)$ did not affect the yields of FAME that ranged between 80 and $91 \%$ (Figure 1a).

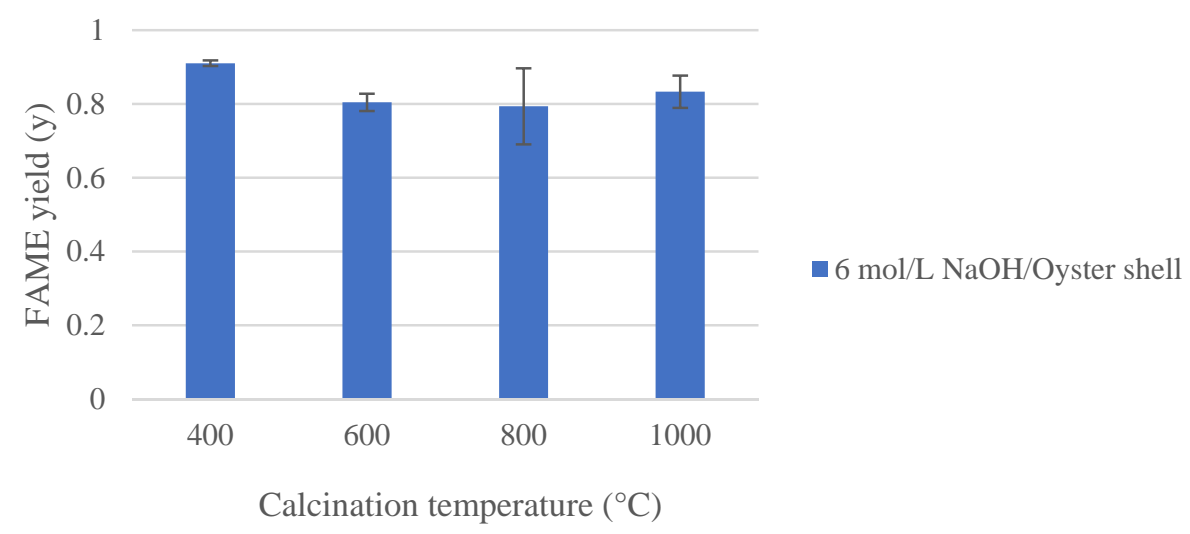

(a)

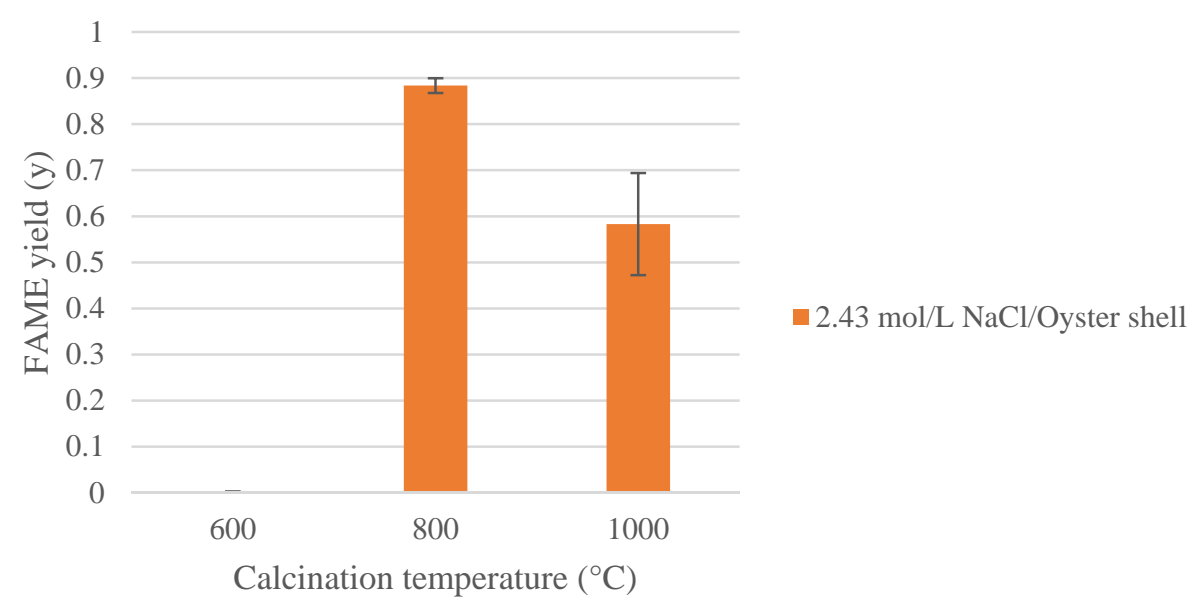

(b)

Figure 2. The FAME yield of the transesterification reaction catalyzed by $\mathrm{NaOH}_{6} /$ shell (a) and $\mathrm{NaCl}_{2.43} /$ shell (b) calcined at various temperatures. Transesterification conditions: temperature $=62{ }^{\circ} \mathrm{C}$; stirring rate $=800 \mathrm{rpm} ; \mathrm{MR}=12 ; \mathrm{CL}=10 \%$. 
However, since the stability of catalyst depends on the calcination temperature, further experiments were conducted to evaluate the reusability of the catalysts calcined at all temperatures. The catalysts were reused consecutively for five times using fresh batches of methanol and oil to determine the yields of FAME. As shown in Figure 3, catalysts calcined at $400{ }^{\circ} \mathrm{C}$ started losing activity after the second run and provided a FAME yield of $26.2 \%$ after the fifth run. However, when calcination temperature was increased, the stability of the catalyst appeared to improve.

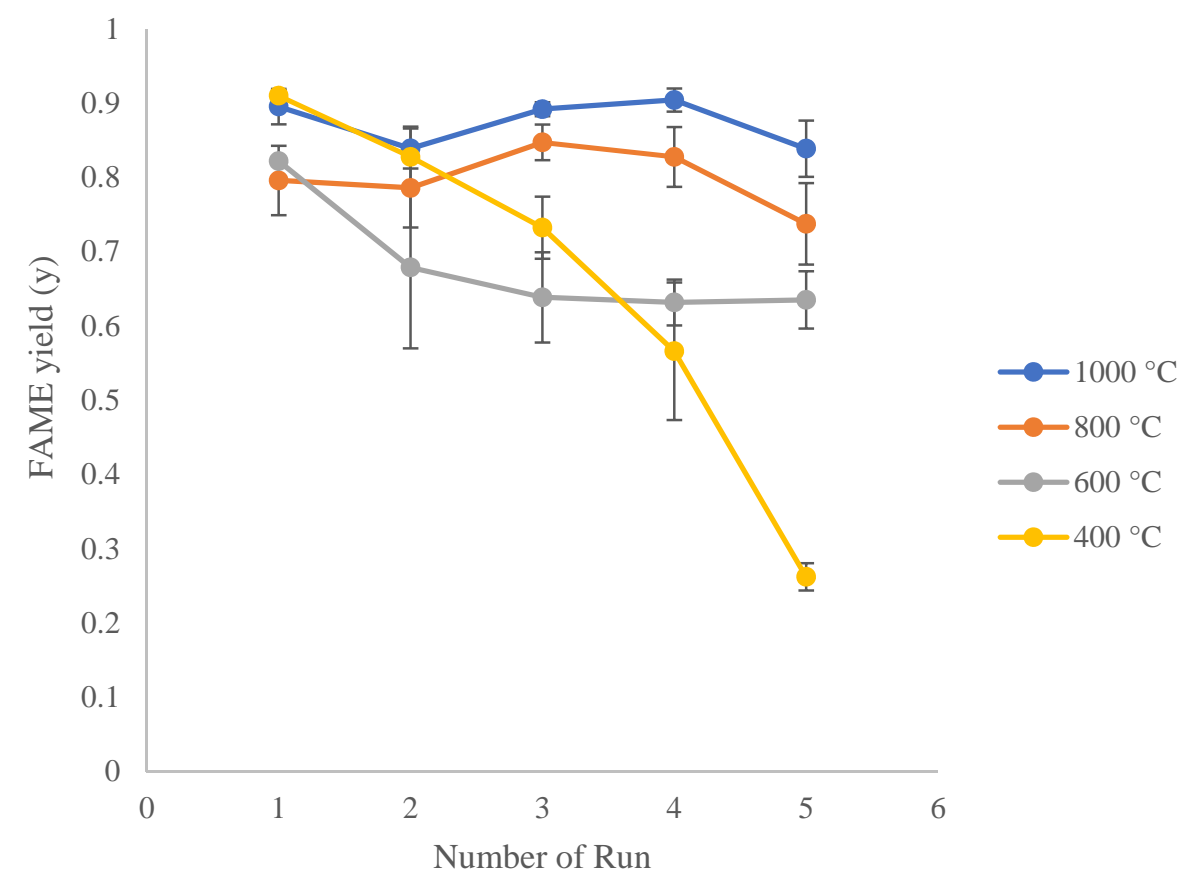

Figure 3. The FAME yield of repeated transesterifications reaction catalyzed by the same spent $\mathrm{NaOH}_{6} /$ shell calcined at various temperatures. Transesterification conditions: temperature $=62{ }^{\circ} \mathrm{C}$; stirring rate $=800 \mathrm{rpm} ; \mathrm{MR}=12 ; \mathrm{CL}=10 \%$.

The catalysts calcined at 800 and $1000{ }^{\circ} \mathrm{C}$ exhibited similar FAME yields for all five runs whereas the catalyst calcined at $600{ }^{\circ} \mathrm{C}$ provided lower FAME yields after the third run, when compared to 800 and $1000^{\circ} \mathrm{C}$ suggesting that calcination at higher temperatures allowed for adequate reaction between Na ions and oyster shell resulting in strong binding of active sites on the surface.

For $\mathrm{NaCl} /$ shell, almost no activity was observed at $600{ }^{\circ} \mathrm{C}$ (FAME yield of $\sim 0.1 \%$ ) (Figure $2 \mathrm{~b}$ ). When the calcination temperature was increased to $800{ }^{\circ} \mathrm{C}$ the yield of FAME increased to $88.4 \%$ and started to decrease with an increase in calcination temperature beyond $800^{\circ} \mathrm{C}$.

Overall, it appears that $\mathrm{NaOH} /$ shell and $\mathrm{NaCl} /$ shell calcined at $800{ }^{\circ} \mathrm{C}$ provided best FAME yields and stability. Hence to elucidate the role of calcination and effects of precursor concentrations, the surface properties of catalysts synthesized under various conditions were studied in detail.

\subsection{Catalyst Characterization}

The specific surface areas and basicities of the catalysts synthesized are summarized in Table 1. The impregnation of $\mathrm{NaOH}$ or $\mathrm{NaCl}$ lowered the specific surface area of the oyster shell, probably because of deposition of precursor molecules within the pores of COS. Our results were similar to those noted by Alburquerque et al., who observed $90-98 \%$ reduction in surface area of SBA- 15 support when $4-20 \%(w / w) \mathrm{CaO}$ was impregnated [18]. Similarly, de Luna et al., impregnated $\mathrm{NaOH}$ on pumice stone to enhance its catalytic activity [17]. The authors reported a significant reduction in surface area and pore volume after impregnation due formation of active sites within the pores. In our research, 
the basicity, however, showed no substantial difference between all types of catalysts, indicating that the precursor type and concentration calcination temperature did not alter the catalysts' basicity.

Table 1. The specific surface areas and basicities of COS, $\mathrm{NaOH}_{6} /$ shell- $400, \mathrm{NaOH}_{6} /$ shell- 800 , $\mathrm{NaCl}_{2.43}$ / shell-600, $\mathrm{NaCl}_{2.43} /$ shell-800 and $\mathrm{NaCl}_{2.43}$ / shell-1000.

\begin{tabular}{|c|c|c|}
\hline Catalyst & Surface Area $/ \mathrm{m}^{2} \mathrm{~g}^{-1}$ & Basicity/mmol $\mathrm{g}^{-1}$ \\
\hline $\cos$ & 2.15 & 11.9 \\
\hline $\mathrm{NaOH}_{6} /$ shell-400 & 0.43 & 13.5 \\
\hline $\mathrm{NaOH}_{6} /$ shell-800 & 0.56 & 12.7 \\
\hline $\mathrm{NaCl}_{2.43} /$ shell-600 & 0.31 & 11.9 \\
\hline $\mathrm{NaCl}_{2.43} /$ shell-800 & 0.31 & 13.4 \\
\hline $\mathrm{NaCl}_{2.43} /$ shell-1000 & 0.69 & 13.3 \\
\hline
\end{tabular}

The XRD pattern of each catalyst is shown in Figure 4a. For NaOH-impregnated shells, major phases formed on the surface of $\mathrm{NaOH}_{6} /$ shell-400 were $\mathrm{CaCO}_{3}, \mathrm{Na}_{2} \mathrm{CO}_{3}$ and $\mathrm{Ca}(\mathrm{OH})_{2}$. Since $\mathrm{CaCO}_{3}$ and $\mathrm{Na}_{2} \mathrm{CO}_{3}$ are not catalytically very active for transesterification, it may be concluded that the catalytic activity of $\mathrm{NaOH}_{6} /$ shell-400 may be due to $\mathrm{Ca}(\mathrm{OH})_{2}$. These results were similar to the results obtained by Kumar and Ali, who used $\mathrm{KOH}$ to modify the surface of $\mathrm{CaO}$ [19]. The as-synthesized nanocrystalline $3.5 \% \mathrm{~K}-\mathrm{CaO}$ exhibited newly generated $\mathrm{Ca}(\mathrm{OH})_{2}$ sites on the surface that contributed to the increased basic strength from $9.8<\mathrm{H}_{-}<10.1$ to $11.1<\mathrm{H}_{-}<15.0$. The activity was also improved as the FAME yield reached $98 \%$ in $75 \mathrm{~min}$ [19]. In our research, when the calcination temperature increased (from $400^{\circ} \mathrm{C}$ to $800^{\circ} \mathrm{C}$ ), the type of surface species changed on the shells' surface. The major phases formed on the surface of $\mathrm{NaOH}_{6}$ / shell- 800 were $\mathrm{CaO}$ and $\mathrm{Na}_{2} \mathrm{O}_{2}$, both of which are catalytically active in transesterification. The formation of alkaline oxide was also observed in the $\mathrm{KNO}_{3}$ impregnated $\mathrm{CaO}-\mathrm{ZnO}$ catalyst synthesized by Istabdi et al. [20]. The as-synthesized catalysts acquired $\mathrm{K}_{2} \mathrm{O}$ on the surface, which might have resulted in the improved activity in the transesterification of soybean oil. A similar trend was observed in our research as well, in which, up to $90 \%$ FAME yields were obtained from the $\mathrm{NaOH}_{6} /$ shell-800 (Figure 1). It appeared that calcination at higher temperature allowed for decomposition of carbonate and hydroxide to respective oxides that are active and stable. In addition, as shown in the reusability experiments (Figure 3), $\mathrm{NaOH}_{6} /$ shell-800 provided high FAME yield even after five successive runs whereas the FAME yields for $\mathrm{NaOH}_{6} /$ shell-400 continually decreased to $26.2 \%$ after the fifth run, indicating a substantial loss of activity.

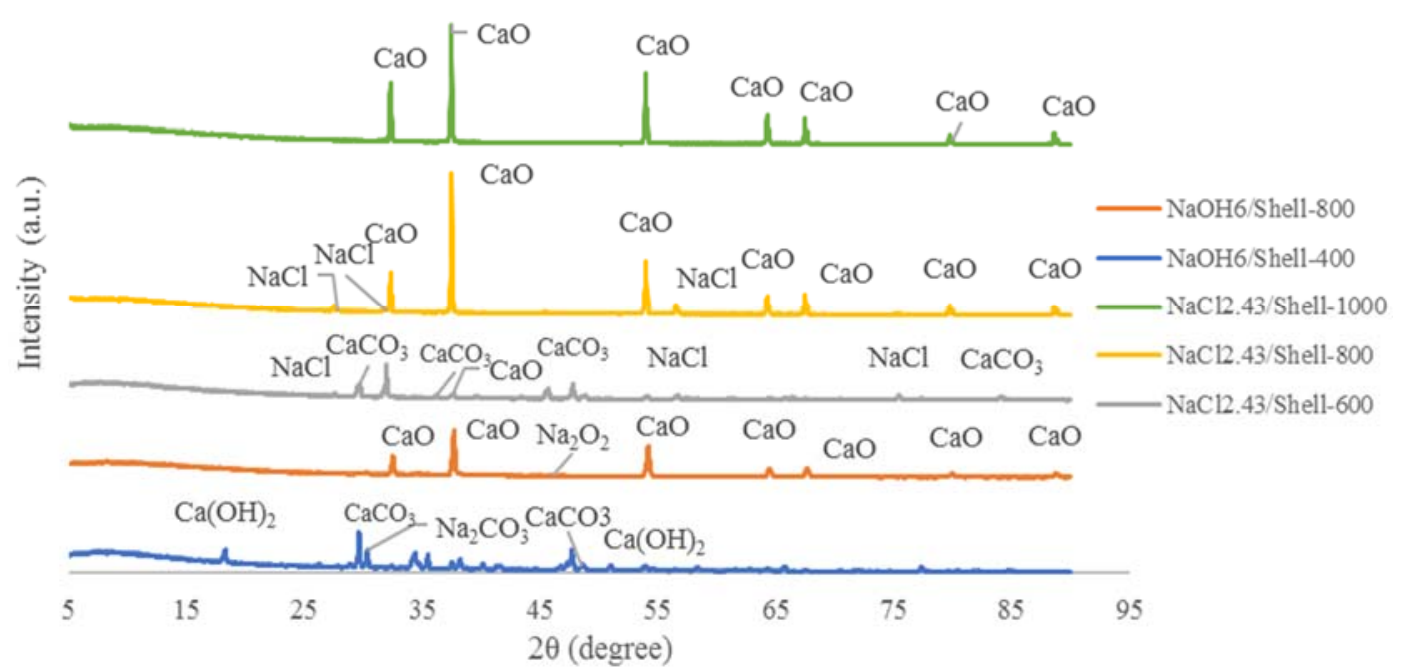

(a)

Figure 4. Cont. 


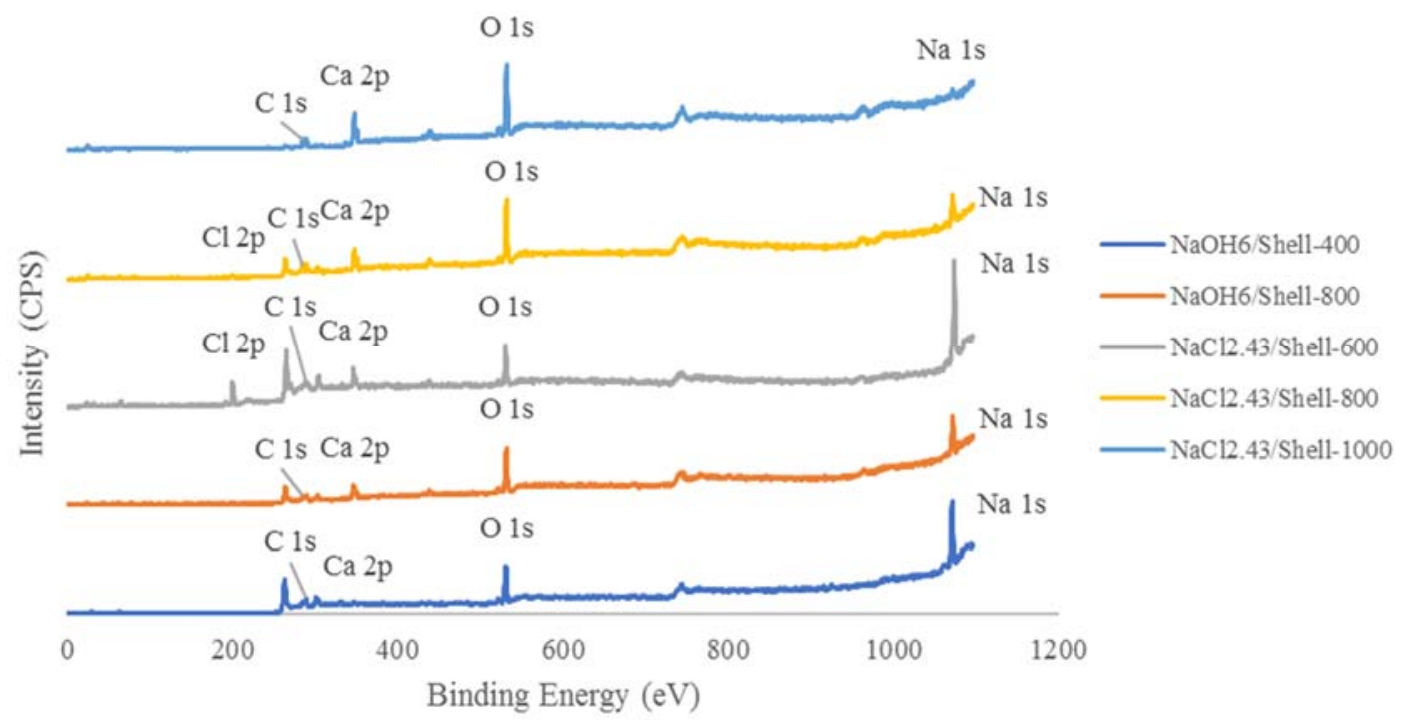

(b)

Figure 4. The XRD (a) and XPS (b) spectra of the sodium-supported oyster shell catalysts.

The XRD patterns of $\mathrm{NaCl}_{2.43}$ / shell-600, $\mathrm{NaCl}_{2.43}$ / shell-800 and $\mathrm{NaCl}_{2.43} /$ shell-1000 are also shown in Figure 4a. At $600{ }^{\circ} \mathrm{C}$, the major phases identified were $\mathrm{CaCO}_{3}$ and $\mathrm{NaCl}$ and traces of $\mathrm{CaO}$. As a result, $\mathrm{NaCl}_{2.43} /$ shell-600 provided only $0.13 \%$ FAME yield after $2 \mathrm{~h}$. When the calcination temperature increased to $800{ }^{\circ} \mathrm{C}$, most $\mathrm{CaCO}_{3}$ had been decomposed into $\mathrm{CaO}$, resulting in the disappearance of $\mathrm{CaCO}_{3}$ and increase in the intensity of $\mathrm{CaO}$ peaks as was also reported by Madhu et al. [21]. Because $\mathrm{CaO}$ is also an active catalyst, the FAME yield from $\mathrm{NaCl}_{2.43} / \mathrm{shell}^{-800}$ increased up to $88.4 \%$. Further increase in the calcination temperature to $1000{ }^{\circ} \mathrm{C}$, however, decreased the yield to $58.3 \%$. As seen from the XRD pattern for $\mathrm{NaCl}_{2.43} /$ shell-1000, only $\mathrm{CaO}$ was detected on the surface. The disappearance of $\mathrm{NaCl}$ in $\mathrm{NaCl}_{2.43}$ / shell-1000 might have caused the FAME yield to decrease. These results implied that a synergistic effect between $\mathrm{NaCl}$ and $\mathrm{CaO}$ on the surface of $\mathrm{NaCl}_{2.43}$ /shell-800 may have resulted in high FAME yields when compared to yields obtained from $\mathrm{NaCl}_{2.43} /$ shell-1000.

The XPS analyses of $\mathrm{NaOH}$-impregnated catalysts indicated different elemental distribution for $\mathrm{NaOH}_{6} /$ shell-400 and $\mathrm{NaOH}_{6}$ / shell-800 catalysts (Figure $4 \mathrm{~b}$ and Table 2). The atomic percentage of $\mathrm{Na}$ in $\mathrm{NaOH}_{6} /$ shell-400 was $42.6 \%$, whereas the atomic percentage of $\mathrm{Na}$ dropped to $16.6 \%$ in $\mathrm{NaOH}_{6} /$ shell-800 as the calcination temperature increased from 400 to $800{ }^{\circ} \mathrm{C}$. However, the atomic percentage of $\mathrm{Ca}$ in $\mathrm{NaOH}_{6}$ / shell-400 increased from $1.4 \%$ to $9.3 \%$ as the calcination temperature increased from 400 to $800{ }^{\circ} \mathrm{C}$. Combined with the XRD results, the Na from the surface of $\mathrm{NaOH}_{6} /$ shell-400 probably originated from $\mathrm{Na}_{2} \mathrm{CO}_{3}$. When the calcination temperature increased, the $\mathrm{Na}_{2} \mathrm{CO}_{3}$ and $\mathrm{CaCO}_{3}$ probably decomposed into $\mathrm{Na}_{2} \mathrm{O}_{2}$ and $\mathrm{CaO}$ as was revealed from XRD spectra.

Table 2. Composition and ratios of surface elements of $\mathrm{NaOH} /$ shell.

\begin{tabular}{ccccccc}
\hline Temperature & $\mathbf{C} 1 \mathbf{s}$ & $\mathbf{O} 1 \mathbf{s}$ & Na 1s & Ca 2p & O/C & $\mathbf{N a} / \mathrm{C}$ \\
\hline $400{ }^{\circ} \mathrm{C}$ & $7.0 \%$ & $49.0 \%$ & $42.6 \%$ & $1.4 \%$ & 7.0 & 6.08 \\
$800{ }^{\circ} \mathrm{C}$ & $29.3 \%$ & $44.7 \%$ & $16.6 \%$ & $9.3 \%$ & 1.52 & 0.56 \\
\hline
\end{tabular}

Figure $5 \mathrm{~A}$ presented the $\mathrm{C} 1 \mathrm{~s}, \mathrm{Ca} 2 \mathrm{p}, \mathrm{Na} 1 \mathrm{~s}$, and $\mathrm{O} 1 \mathrm{~s}$ regions for $\mathrm{NaOH}_{6} / \mathrm{Shell}^{-400}$ and $\mathrm{NaOH}_{6} / \mathrm{Shell}_{-}-800$. In the $\mathrm{C} 1 \mathrm{~s}$ region, both catalysts showed doublet peaks $(285.0 \mathrm{eV}$ and $289.2 \mathrm{eV}$ for $\mathrm{NaOH}_{6} /$ Shell-400 and $285.0 \mathrm{eV}$ and $289.5 \mathrm{eV}$ for NaOH6/Shell-800), suggesting that they contained $\mathrm{C}-\mathrm{H}$ and carbonate groups on the surface, probably from the air contamination [18]. In the Ca $2 \mathrm{p}$ region, $\mathrm{NaOH}_{6} /$ Shell- 400 showed two peaks at $346.5 \mathrm{eV}$ and $350.1 \mathrm{eV}$, suggesting that the Ca originated 
from $\mathrm{CaCO}_{3}$ [22]. $\mathrm{NaOH}_{6} /$ Shell- 800 showed two peaks at $346.8 \mathrm{eV}$ and $350.3 \mathrm{eV}$, suggesting that the $\mathrm{Ca}$ originated from $\mathrm{CaO}$ [23]. Similarly, in the $\mathrm{Na} 1 \mathrm{~s}$ region, both catalysts displayed doublet peaks. In our analyses, the two peaks in both catalysts seemed to shift to lower BE by $1.0 \mathrm{eV}$ compared with the references [24-26]. Combined with the details of the preparation method and the XRD results, the $\mathrm{Na}$ 1s peak at lower $\mathrm{BE}$ might have originated from $\mathrm{Na}_{2} \mathrm{CO}_{3}$, while the $\mathrm{Na}$ 1s peak at higher BE might be associated with $\mathrm{NaOH}$ and $\mathrm{Na}_{2} \mathrm{O}_{2}$ for $\mathrm{NaOH}_{6} /$ Shell- 400 and $\mathrm{NaOH}_{6} /$ Shell-800, respectively [24-26]. In the $\mathrm{O} 1 \mathrm{~s}$ region, $\mathrm{NaOH}_{6} /$ Shell-400 displayed doublet peaks at $530.3 \mathrm{eV}$ and $531.2 \mathrm{eV}$, assigned to $\mathrm{CaO}$ and $\mathrm{Ca}(\mathrm{OH})_{2}$, respectively $[27,28]$. Similarly, $\mathrm{NaOH}_{6} /$ Shell-800 exhibited doublet peaks at $530.3 \mathrm{eV}$ and $531.5 \mathrm{eV}$, assigned to $\mathrm{Na}_{2} \mathrm{O}_{2}$ and $\mathrm{CaO}$ [29], respectively, based on the XRD analysis. This doublet feature indicated that some of the surface oxygen had been shifted to lower BE for both catalysts, when compared to control (calcined oyster shell), acquiring a higher effective negative charge. As was also observed in our recent research [16], the shift in oxygen would have enhanced the electron donating ability, suggesting that the surface oxygen was more basic [30]. As a result, the increased electron donating ability may have allowed triglyceride and methanol to form a tetrahedral intermediate that may have resulted in FAME after structural rearrangement [2].
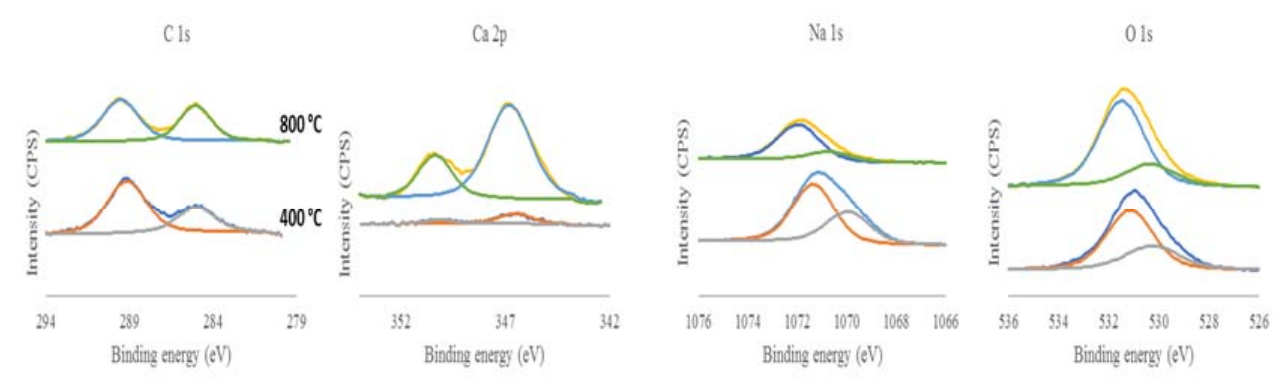

(A)
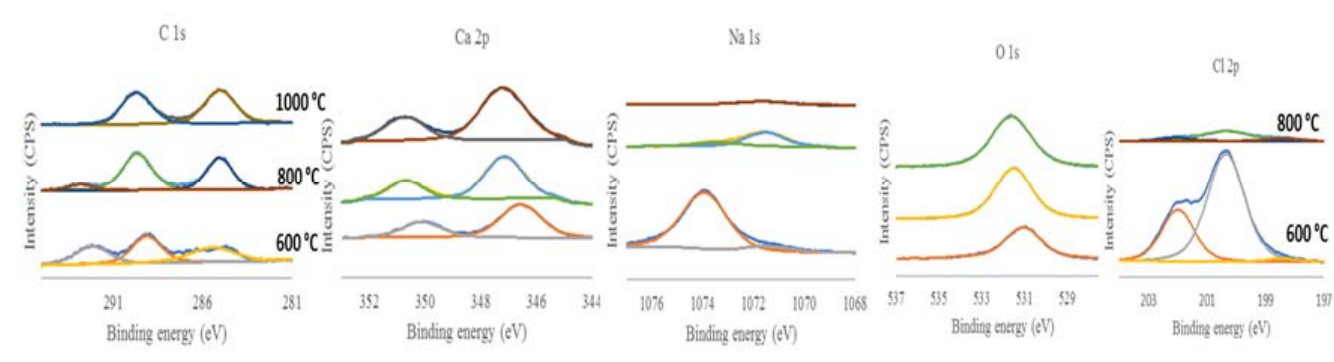

(B)

Figure 5. The elemental XPS peaks were deconvoluted for (A) $\mathrm{NaOH}$ supported oyster shell $\left(\mathrm{NaOH}_{6} /\right.$ Shell-400 (bottom) and $\mathrm{NaOH}_{6} /$ Shell-800 (top) and (B) $\mathrm{NaCl} /$ Oyster shell $\left(\mathrm{NaCl}_{2.43} /\right.$ Shell-600 (bottom), $\mathrm{NaCl}_{2.43}$ /Shell-800 (middle) and $\mathrm{NaCl}_{2.43}$ /Shell-1000 (top). For Cl 2p, $\mathrm{NaCl}_{2.43} /$ Shell-600 (bottom) and $\mathrm{NaCl}_{2.43} /$ Shell-800 (top)).

The XPS data obtained from NaCl-impregnated catalysts also revealed different elemental distributions for $\mathrm{NaCl}_{2.43}$ /shell-600, $\mathrm{NaCl}_{2.43}$ /shell-800, and $\mathrm{NaCl}_{2.43} /$ shell-1000 (Table 3). As the calcination temperature increased, the amount of $\mathrm{Na}$ and $\mathrm{Cl}$ decreased continuously from $32.4 \%$ (Na) and $15.0 \%(\mathrm{Cl})$ (for $600{ }^{\circ} \mathrm{C}$ calcination) to $10.0 \%$ and $2.1 \%$ (for $800{ }^{\circ} \mathrm{C}$ calcination), and finally dropped to $1.2 \%$ and $0 \%$ (for $1000{ }^{\circ} \mathrm{C}$ calcination), respectively, while the amount of Ca increased from $5.8 \%\left(600{ }^{\circ} \mathrm{C}\right)$ to $10.3 \%\left(800^{\circ} \mathrm{C}\right)$, and finally reached $15.8 \%\left(1000^{\circ} \mathrm{C}\right)$. These observations were consistent with the XRD results, in which the major phases of the catalyst, as the calcination temperature 
increased, changed from carbonate to oxide for the $\mathrm{Ca}$, and the intensity of $\mathrm{NaCl}$ phase was attenuated continuously and disappeared finally at $1000^{\circ} \mathrm{C}$.

Table 3. Composition and ratios of surface elements of $\mathrm{NaCl} /$ shell.

\begin{tabular}{cccccccc}
\hline Temperature & C 1s & O 1s & Cl 2p & Na 1s & Ca 2p & O/C & Na/C \\
\hline $600{ }^{\circ} \mathrm{C}$ & $22.5 \%$ & $24.2 \%$ & $15.0 \%$ & $32.4 \%$ & $5.8 \%$ & 1.07 & 1.44 \\
$800{ }^{\circ} \mathrm{C}$ & $32.1 \%$ & $45.5 \%$ & $2.1 \%$ & $10.0 \%$ & $10.3 \%$ & 1.42 & 0.31 \\
$1000^{\circ} \mathrm{C}$ & $27.6 \%$ & $55.4 \%$ & $0 \%$ & $1.2 \%$ & $15.8 \%$ & 2.00 & 0.04 \\
\hline
\end{tabular}

Figure 5B presented the $\mathrm{C} 1 \mathrm{~s}, \mathrm{Ca} 2 \mathrm{p}, \mathrm{Na} 1 \mathrm{~s}, \mathrm{O} 1 \mathrm{~s}$ and $\mathrm{Cl} 2 \mathrm{p}$ regions for $\mathrm{NaCl}_{2.43} / \mathrm{Shell}-600$, $\mathrm{NaCl}_{2.43} /$ Shell-800 and $\mathrm{NaCl}_{2.43} /$ Shell-1000. In the $\mathrm{C} 1 \mathrm{~s}$ region, $\mathrm{NaCl}_{2.43} /$ Shell-600 and $\mathrm{NaCl}_{2.43} /$ Shell-800 exhibited triplet peaks while $\mathrm{NaCl}_{2.43} /$ Shell-1000 showed doublet peaks. In addition to peaks at $\sim 289.4 \mathrm{eV}$ and $\sim 285.0 \mathrm{eV}$ (assigned to C-H and carbonate groups, respectively) [18], $\mathrm{NaCl}_{2.43}$ /Shell-600 and $\mathrm{NaCl}_{2.43}$ /Shell-800 also displayed a third $\mathrm{C}$ 1s peak at $\sim 292.4 \mathrm{eV}$, which may be attributed to the existence of $\mathrm{C}-\mathrm{Cl}$ [31]. $\mathrm{NaCl}_{2.43} /$ Shell-1000 did not contain $\mathrm{Cl}$, and thus no such peak was detected. In the $\mathrm{Ca} 2 \mathrm{p}$ region, all three catalysts showed doublet peaks. The peaks at $346.6 \mathrm{eV}$ and $350.1 \mathrm{eV}$ in $\mathrm{NaCl}_{2.43}$ /Shell- 600 were assigned to $\mathrm{CaCO}_{3}$ [22]. The peaks at $347.1 \mathrm{eV}$ and $350.6 \mathrm{eV}$ in $\mathrm{NaCl}_{2.43} /$ Shell-800 and at $347.2 \mathrm{eV}$ and $350.7 \mathrm{eV}$ in $\mathrm{NaCl}_{2.43} /$ Shell-1000 were assigned to $\mathrm{CaO}$ [29]. In the Na region, $\mathrm{NaCl}_{2.43} /$ Shell- 600 and $\mathrm{NaCl}_{2.43} /$ Shell-800 displayed doublet peaks at $\sim 1073.6 \mathrm{eV}$ and $\sim 1071.5 \mathrm{eV}$, assigned to $\mathrm{NaCl}$ [32] and $\mathrm{Na}_{2} \mathrm{CO}_{3}$ [25], respectively, while $\mathrm{NaCl}_{2.43} /$ Shell-1000 only showed single peak at $1071.6 \mathrm{eV}$, assigned to $\mathrm{Na}_{2} \mathrm{CO}_{3}$ [25]. The $\mathrm{Na}_{2} \mathrm{CO}_{3}$ in $\mathrm{NaCl}_{2.43}$ /Shell-600 may be attributed to adsorbed $\mathrm{Na}$ and undecomposed carbonate in the shell matrix, while the $\mathrm{Na}_{2} \mathrm{CO}_{3}$ in $\mathrm{NaCl}_{2.43} /$ Shell- 800 and $\mathrm{NaCl}_{2.43}$ /Shell-1000 might be attributed to the air contaminant on the surface since no carbonate group was detected based on the XRD analysis. Because $\mathrm{NaCl}_{2.43} /$ Shell-1000 did not contain $\mathrm{Cl}$, it did not exhibit a peak representing $\mathrm{NaCl}$. In the $\mathrm{O}$ 1s region, all three catalysts exhibited a single peak. The peak at $531.0 \mathrm{eV}$ of $\mathrm{NaCl}_{2.43} / \mathrm{Shell}^{-600}$ was assigned to $\mathrm{CaCO}_{3}$ [23] and the peak at $531.5 \mathrm{eV}$ of $\mathrm{NaCl}_{2.43} / \mathrm{Shell}-800$ and the peak at $531.6 \mathrm{eV}$ of $\mathrm{NaCl}_{2.43} /$ Shell-1000 were assigned to $\mathrm{CaO}$ [29]. In the $\mathrm{Cl} 2 \mathrm{p}$ region, both $\mathrm{NaCl}_{2.43} / \mathrm{Shell}_{-600}$ and $\mathrm{NaCl}_{2.43} /$ Shell-800 displayed doublet peaks at $200.3 \mathrm{eV}$ and $202.0 \mathrm{eV}$, for $2 \mathrm{p} 3 / 2$ and $2 \mathrm{p} 1 / 2$ components of $\mathrm{Cl}$, respectively, with a separation of $1.7 \mathrm{eV}$ that was also observed by Wu et al. [33]. In addition, $\mathrm{NaCl}_{2.43} /$ Shell-800 also had a third peak at lower BE, $198.4 \mathrm{eV}$. Comparing the FAME yields of $\mathrm{NaCl}_{2.43} /$ Shell-800 with $\mathrm{NaCl}_{2.43}$ /Shell-1000 indicated that $\mathrm{NaCl}_{2.43} /$ Shell-800 resulted in higher FAME yield than $\mathrm{NaCl}_{2.43} /$ Shell-1000. Considering that the $\mathrm{BE}$ of O $1 \mathrm{~s}$ for $\mathrm{NaCl}_{2.43} /$ Shell-800 was comparable with $\mathrm{NaCl}_{2.43}$ /Shell-1000, the enhanced activity of $\mathrm{NaCl}_{2.43}$ /Shell- 800 may have been due to the formation of surface $\mathrm{Cl}$ with lower BE (198.4 eV). As shown in Figure 6, the negatively shifted $\mathrm{Cl}$ probably behaved similarly as the negatively shifted $\mathrm{O}$, thereby increasing the effective negative charge that led to an increase in the electron donating ability and enhanced the FAME production rate by facilitating the formation of the tetrahedral intermediate between adsorbed triglyceride and methanol $[2,30]$. This synergistic effect between $\mathrm{NaCl}$ and $\mathrm{CaO}$ appears to have occurred at $800^{\circ} \mathrm{C}$ because the catalysts calcined at $600{ }^{\circ} \mathrm{C}$ and $100{ }^{\circ} \mathrm{C}$ did not exhibit high activity despite equipped with identical $\mathrm{NaCl}$ loading. 


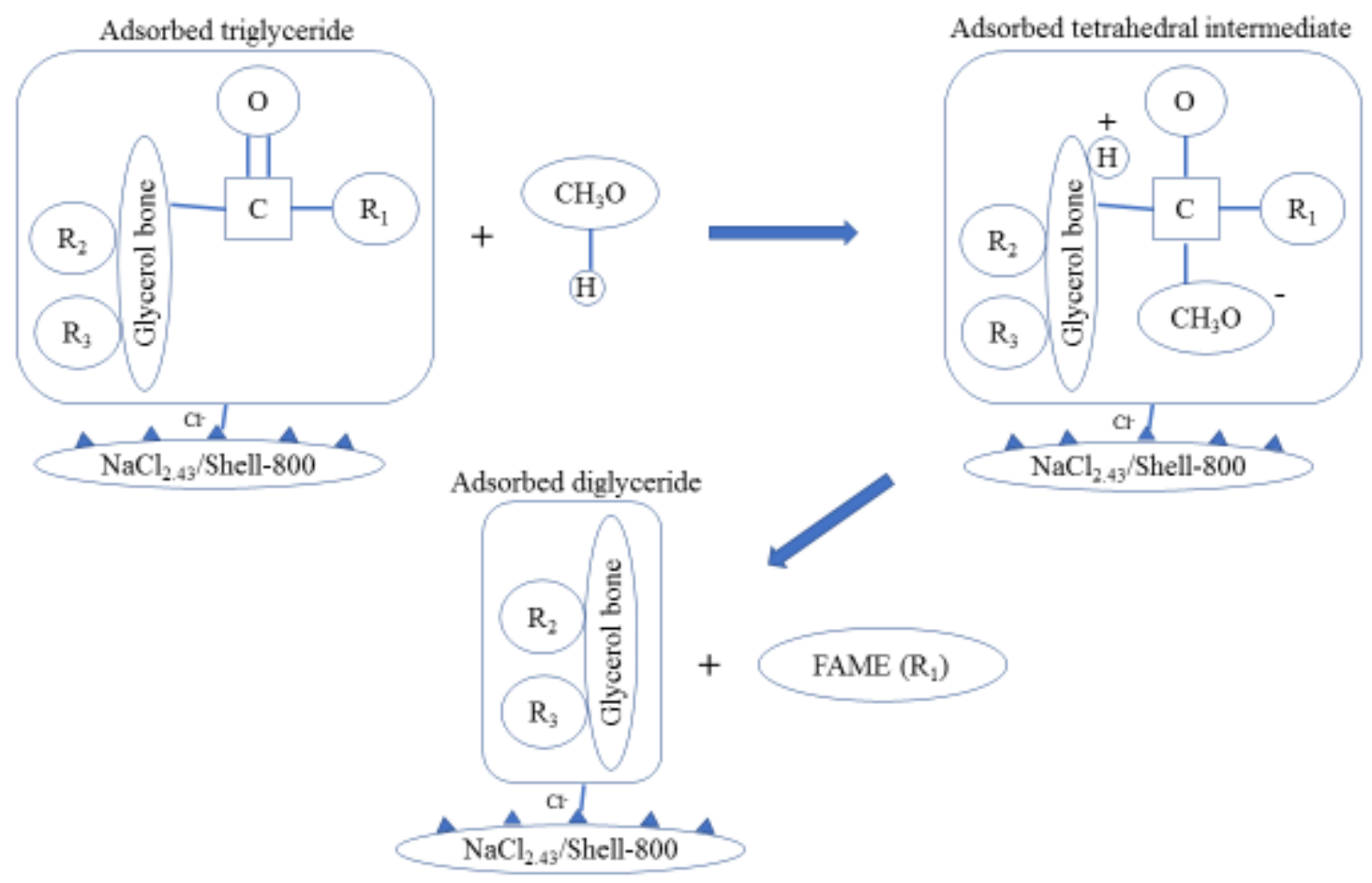

Figure 6. Role of $\mathrm{NaCl}_{2.43}$ /Shell-800 surface basic site on the improved activity.

\section{Materials and Methods}

\subsection{Catalyst Preparation}

Discarded oyster shells were procured locally. The dirt on the shells were cleaned in running water and allowed to dry overnight. Subsequently, the shells were calcined $\left(2 \mathrm{~h} @ 500{ }^{\circ} \mathrm{C}\right)$ and crushed (1-2 mm).

Two types of Na-based precursor solutions were employed in this research: $\mathrm{NaOH}$ and $\mathrm{NaCl}$. Typically, $20 \mathrm{~g}$ of oyster shells were impregnated with $60 \mathrm{~mL}$ of precursor solutions $\left(90{ }^{\circ} \mathrm{C}\right.$ for $5 \mathrm{~h}$ ) of predetermined concentration on a process-controlled hot plate (Isotemp, Fisher Scientific, Pittsburgh, PA). Subsequently, the impregnated shells were filtered and calcined at a predetermined temperature for $3 \mathrm{~h}$ (with a flow of nitrogen).

\subsection{Catalyst Characterization}

The specific surface area of the catalyst synthesized was determined using Quantachrome Monosorb Surface Area Analyzer (Quantachrome Instruments, Boynton Beach, FL, USA) based on the Brunauer-Emmett-Teller (BET) nitrogen adsorption method [16]. Prior to the measurement, all catalysts were degassed at $120^{\circ} \mathrm{C}$ for $8 \mathrm{~h}$.

The basicity of the catalyst was determined as described by Mo et al. [34]. $0.1 \mathrm{~g}$ sample was soaked into $20 \mathrm{~mL}$ of the $0.1 \mathrm{~N} \mathrm{HCl}$ solution for 20 min flowed by titration using $0.15 \mathrm{~N} \mathrm{NaOH}$ with Phenolphthalein.

$X$-ray powder diffraction (XRD) analyses were performed via a PANalytical Empyrean X-ray diffractometer (Malvern Panalytical Ltd., Almelo, Netherlands) with $\mathrm{Cu} K \alpha$ radiation $(\lambda=0.15418 \mathrm{~nm})$ in the $2 \theta$ range of $5^{\circ}-90^{\circ}$. The data were collected as described previously [16].

The samples were also analyzed via X-ray photoelectron spectroscopy (XPS) using a SPECS FlexMod system (SPECS GmbH, Berlin, Germany) equipped with a hemispherical analyzer PHOIBIS 150 and a Mg Kalpha (1254 eV) X-ray source @ 10 ${ }^{-10} \mathrm{mbar}$ ) using adventitious Carbon (C 1s line at $285.0 \mathrm{eV}$ binding energy) as reference. 


\subsection{Transesterification}

Batch experiments were performed (in duplicates) $250 \mathrm{~mL}$ three-neck glass reactors. $20 \mathrm{~mL}$ of soybean oil was reacted $\left(62{ }^{\circ} \mathrm{C}\right.$ and $\left.800 \mathrm{rpm}\right)$ with predetermined amount of methanol and catalyst on a process-controlled hot plate (Isotemp, Fisher Scientific, Pittsburgh, PA, USA). In this research, the molar ratio of methanol to oil (MR) and catalyst loading (CL) were set to 12 and $10 \%$, respectively. After a 2-h reaction, $3 \mathrm{~mL}$ of the reaction mixture was transferred to $15 \mathrm{~mL}$ plastic tubes for centrifugation ( $5000 \mathrm{rpm}$ for $5 \mathrm{~min}$ ) to remove the catalyst. Subsequently, $800 \mu \mathrm{L}$ of the supernatant liquid was drawn and washed three times with DI water from which a $300 \mu \mathrm{L}$ sample was collected for further gas chromatographic analysis.

\subsection{Gas Chromatography Analysis}

A gas chromatograph with a mass spectrometer (Agilent 7890/5975C) was used to separate, detect, and quantify FAME using Methyl Laurate (99\% purity, CAS 111-82-0) as an internal standard as described in Jin et al., (2017b). FAME yields were calculated using the equation below, as proposed by Liu et al and Chung et al $[2,35]$.

$$
\begin{aligned}
& \text { Yield }=\frac{\left(\sum \mathrm{A}\right)-\mathrm{A}_{\mathrm{IS}}}{\mathrm{A}_{\mathrm{IS}}} \times \frac{\mathrm{C}_{\mathrm{IS}} \mathrm{V}}{\mathrm{m}_{\mathrm{FAMES}}} \times 100 \% \approx \frac{\left(\sum \mathrm{A}\right)-\mathrm{A}_{\mathrm{IS}}}{\mathrm{A}_{\mathrm{IS}}} \times \frac{\mathrm{C}_{\mathrm{IS}} \mathrm{V}}{\mathrm{m}_{\text {oil }}} \times 100 \%= \\
& \frac{\left(\sum \mathrm{A}\right)-\mathrm{A}_{I S}}{\mathrm{~A}_{\mathrm{IS}}} \times \frac{\mathrm{C}_{\mathrm{IS}} \times \mathrm{V}}{\rho_{\text {oil }} \times \frac{1}{\mathrm{r}} \times \mathrm{V}} \times 100 \%=\frac{\left(\sum \mathrm{A}\right)-\mathrm{A}_{\mathrm{IIS}}}{\mathrm{A}_{\mathrm{IS}}} \times \frac{\mathrm{C}_{\mathrm{IS}}}{\mathrm{C}_{\text {oil }}} \times 100 \%
\end{aligned}
$$

where $\sum \mathrm{A}$ is the total area of peak areas of all methyl esters, $\mathrm{A}_{\mathrm{IS}}$ is the peak area of Methyl Laurate, $\mathrm{C}_{\mathrm{IS}}$ is the concentration of Methyl Laurate in the solution after dilution $(\mathrm{g} / \mathrm{mL}), \mathrm{V}$ is the volume of the final diluted solution $(\mathrm{mL}), \mathrm{m}_{\text {FAMEs }}$ is the theoretical maximum mass of FAMEs $(\mathrm{g}), \mathrm{m}_{\mathrm{oil}}$ is the mass of pure soybean oil of volume $\mathrm{V}(\mathrm{g}), \rho_{\text {oil }}$ is the density of soybean oil $(\mathrm{g} / \mathrm{mL}), \mathrm{r}$ is the dilution ratio of FAMEs sample, $C_{\mathrm{oil}}$ is the corresponding concentration of soybean oil $(\mathrm{g} / \mathrm{mL})$ in the solution after dilution, if dilution ratio is $\mathrm{r}$.

\subsection{Experimental Design}

All experiments were performed in duplicates. For the synthesis of $\mathrm{NaCl} /$ shell catalyst, $\mathrm{NaCl}$ solutions of 2, 2.43, 3.64, 4, and $6 \mathrm{~mol} / \mathrm{L}$ were employed. Similarly, for the synthesis of $\mathrm{NaOH} / \mathrm{shell}$ catalyst, $\mathrm{NaOH}$ solutions of 2, 4, 6, 8, 10, and 12.5 were used. All catalysts synthesized were tested in batch reactors and the FAME yields were analyzed using SAS (SAS Institute Inc., Cary, NC, USA).

The optimal conditions of each precursor type were chosen based on the FAME yield. The corresponding catalyst was then re-prepared but calcined at various temperatures. For $\mathrm{NaCl}$-impregnated catalysts, calcination temperatures of $600{ }^{\circ} \mathrm{C}, 800{ }^{\circ} \mathrm{C}, 1000{ }^{\circ} \mathrm{C}$ and for $\mathrm{NaOH}$-impregnated catalysts, calcination temperatures of $400{ }^{\circ} \mathrm{C}, 600{ }^{\circ} \mathrm{C}, 800{ }^{\circ} \mathrm{C}$, and $1000{ }^{\circ} \mathrm{C}$ were used.

Additional experiments were performed to test the reusability of the various $\mathrm{NaOH}$-impregnated calcined oyster shells. The spent catalyst was used for five consecutive runs. After each run, the FAME yield was determined and the recovered catalyst was applied to subsequent run without any treatment. The data were analyzed via a Tukey's HSD test.

\section{Conclusions}

This research investigated how preparation conditions affected the structure and activity of transesterification catalysts derived from waste oyster shells. Oyster shells that were impregnated with various concentrations of $\mathrm{NaOH}$ and $\mathrm{NaCl}$ and calcined at different temperatures were tested as catalysts in batch experiments. Based on results obtained from batch experiments and catalyst characterization, it appears that precursor type and calcination temperature determined the formation of newly generated surface species that influenced the activity of the catalyst. In general, higher 
calcination temperature converted more carbonates and hydroxides into oxides that enhanced catalyst activity due to a higher electron donating ability.

Author Contributions: H.J. designed and conducted the experiments, performed the data analysis, and wrote the manuscript; P.K. conceived the idea, supervised the research and edited the manuscript; J.J.C. and S.W.P. contributed to the catalyst characterization and reaction mechanisms of the transesterification reaction. J.A.O. contributed to the experimental design and data analysis.

Acknowledgments: The authors thank Chung, Fred Stevie, Andrew Whitaker, and Maia Fitzstevens for the help on catalyst characterization, Tu for the help on the experiment supplies and Department of Biological and Agricultural Engineering for funding support. This work was performed in part at the Analytical Instrumentation Facility (AIF) at North Carolina State University, which is supported by the State of North Carolina and the National Science Foundation (award number ECCS-1542015). The AIF is a member of the North Carolina Research Triangle Nanotechnology Network (RTNN), a site in the National Nanotechnology Coordinated Infrastructure (NNCI).

Conflicts of Interest: The authors declare no conflict of interest.

\section{References}

1. Kawashima, A.; Matsubara, K.; Honda, K. Development of heterogeneous base catalysts for biodiesel production. Bioresour. Technol. 2008, 99, 3439-3443. [CrossRef] [PubMed]

2. Liu, X.; He, H.; Wang, Y.; Zhu, S.; Piao, X. Transesterification of soybean oil to biodiesel using CaO as a solid base catalyst. Fuel 2008, 87, 216-221. [CrossRef]

3. Meher, L.C.; Kulkarni, M.G.; Dalai, A.K.; Naik, S.N. Transesterification of karanja (Pongamia pinnata) oil by solid basic catalysts. Eur. J. Lipid Sci. Technol. 2006, 108, 389-397. [CrossRef]

4. Watkins, R.S.; Lee, A.F.; Wilson, K. Li-CaO catalysed tri-glyceride transesterification for biodiesel applications. Green Chem. 2004, 6, 335-340. [CrossRef]

5. Mar, W.W.; Somsook, E. Methanolysis of soybean oil over $\mathrm{KCl} / \mathrm{CaO}$ solid base catalyst for biodiesel production. Sci. Asia 2012, 38, 90-94. [CrossRef]

6. Wen, L.; Wang, Y.; Lu, D.; Hu, S.; Han, H. Preparation of KF/CaO nanocatalyst and its application in biodiesel production from Chinese tallow seed oil. Fuel 2010, 89, 2267-2271. [CrossRef]

7. Liu, C.C.; Lu, W.C.; Liu, T.J. Transesterification of soybean oil using CsF/CaO catalysts. Energy Fuels 2012, 26, 5400-5407. [CrossRef]

8. Mahesh, S.E.; Ramanathan, A.; Begum, K.M.M.S.; Narayanan, A. Biodiesel production from waste cooking oil using KBr impregnated $\mathrm{CaO}$ as catalyst. Energy Convers. Manag. 2015, 91, 442-450. [CrossRef]

9. Yan, S.; Kim, M.; Mohan, S.; Salley, S.O.; Ng, K.Y.S. Effects of preparative parameters on the structure and performance of Ca-La metal oxide catalysts for oil transesterification. Appl. Catal. A Gen. 2010, 373, 104-111. [CrossRef]

10. Kaur, N.; Ali, A. Kinetics and reusability of $\mathrm{Zr} / \mathrm{CaO}$ as heterogeneous catalyst for the ethanolysis and methanolysis of Jatropha crucas oil. Fuel Process. Technol. 2014, 119, 173-184. [CrossRef]

11. Wei, Z.; Xu, C.; Li, B. Application of waste eggshell as low-cost solid catalyst for biodiesel production. Bioresour. Technol. 2009, 100, 2883-2885. [CrossRef] [PubMed]

12. Rezaei, R.; Mohadesi, M.; Moradi, G.R. Optimization of biodiesel production using waste mussel shell catalyst. Fuel 2013, 109, 534-541. [CrossRef]

13. Suryaputra, W.; Winata, I.; Indraswati, N.; Ismadji, S. Waste capiz (Amusium cristatum) shell as a new heterogeneous catalyst for biodiesel production. Renew. Energy 2013, 50, 795-799. [CrossRef]

14. Jairam, S.; Kolar, P.; Sharma-Shivappa Ratna, R.; Osborne, J.A.; Davis, J.P. KI-impregnated oyster shell as a solid catalyst for soybean oil transesterification. Bioresour. Technol. 2012, 104, 329-335. [CrossRef] [PubMed]

15. Jin, H.; Kolar, P.; Peretti, S.W.; Osborne, J.A.; Cheng, J.J. NaOH-impregnated oyster shell as a solid base catalyst for transesterification of soybean oil. Int. J. Agric. Biol. Eng. 2017. accepted.

16. Jin, H.; Kolar, P.; Peretti, S.W.; Osborne, J.A.; Cheng, J.J. Kinetics and mechanism of NaOH-impregnated calcined oyster shell-catalyzed transesterification of soybean oil. Energies 2017, 10, 1920. [CrossRef]

17. De Luna, M.D.G.; Cuasay, J.L.; Tolosa, N.C.; Chung, T.W. Transesterification of soybean oil using a novel heterogeneous base catalyst: Synthesis and characterization of Na-pumice catalyst, optimization of 
transesterification conditions, studies on reaction kinetics and catalyst reusability. Fuel 2017, 209, $246-253$. [CrossRef]

18. Albuquerque, M.C.G.; Jiménez-Urbistondo, I.; Santamaría-González, J.; Mérida-Robles, J.M.; Moreno-Tost, R.; Rodríguez-Castellón, E.; Jiménez-López, A.; Azevedo, D.C.S.; Cavalcante, C.L.; Maireles-Torres, P. CaO supported on mesoporous silicas as basic catalysts for transesterification reactions. Appl. Catal. A Gen. 2008, 334, 35-43. [CrossRef]

19. Kumar, D.; Ali, A. Nanocrystalline K-CaO for the transesterification of a variety of feedstocks: Structure, kinetics and catalytic properties. Biomass Bioenergy 2012, 46, 459-468. [CrossRef]

20. Istadi, I.; Prasetyo, S.A.; Nugroho, T.S. Characterization of $\mathrm{K}_{2} \mathrm{O} / \mathrm{CaO}-\mathrm{ZnO}$ Catalyst for Transesterification of Soybean Oil to Biodiesel. Procedia Environ. Sci. 2015, 23, 394-399. [CrossRef]

21. Madhu, D.; Chavan, S.B.; Singh, V.; Singh, B.; Sharma, Y.C. An economically viable synthesis of biodiesel from a crude Millettia pinnata oil of Jharkhand, India as feedstock and crab shell derived catalyst. Bioresour. Technol. 2016, 214, 210-217. [CrossRef] [PubMed]

22. Ni, M.; Ratner, B.D. Differentiating calcium carbonate polymorphs by surface analysis techniques-An XPS and TOF-SIMS study. Surf. Interface Anal. 2008, 40, 1356-1361. [CrossRef] [PubMed]

23. Demri, B.; Muster, D. XPS study of some calcium compounds. J. Mater. Process. Technol. 1995, 55, 311-314. [CrossRef]

24. Hammond, J.S.; Holubka, J.W.; deVries, J.E.; Dickie, R.A. The application of x-ray photo-electron spectroscopy to a study of interfacial composition in corrosion-induced paint de-adhesion. Corros. Sci. 1981, 21, 239-253. [CrossRef]

25. Siriwardane, R.V.; Cook, J.M. Interactions of $\mathrm{NO}$ and $\mathrm{SO}_{2}$ with iron deposited on silica. J. Colloid Interface Sci. 1985, 104, 250-257. [CrossRef]

26. Wu, Q.H.; Thißen, A.; Jaegermann, W. XPS and UPS study of Na deposition on thin film $\mathrm{V}_{2} \mathrm{O}_{5}$. Appl. Surf. Sci. 2005, 252, 1801-1805. [CrossRef]

27. Van Doveren, H.; Verhoeven, J.A.T.H. XPS spectra of $\mathrm{Ca}$, $\mathrm{Sr}, \mathrm{Ba}$ and their oxides. J. Electron Spectrosc. Relat. Phenom. 1980, 21, 265-273. [CrossRef]

28. Sugama, T.; Kukacka, L.E.; Carciello, N.; Hocker, N.J. Study of interactions at water-soluble polymer $/ \mathrm{Ca}(\mathrm{OH})_{2}$ or gibbsite interfaces by XPS. Cem. Concr. Res. 1989, 19, 857-867. [CrossRef]

29. Hanawa, T.; Ota, M. Calcium phosphate naturally formed on titanium in electrolyte solution. Biomaterials 1991, 12, 767-774. [CrossRef]

30. Babu, N.S.; Sree, R.; Prasad, P.S.S.; Lingaiah, N. Room-temperature transesterification of edible and nonedible oils using a heterogeneous strong basic Mg/La catalyst. Energy Fuels 2008, 22, 1965-1971. [CrossRef]

31. Gelius, U.; Hedén, P.F.; Hedman, J.; Lindberg, B.J.; Manne, R.; Nordberg, R.; Nordling, C.; Siegbahn, K. Molecular Spectroscopy by Means of ESCA: III Carbon Compounds. Phys. Scr. 1970, 2, 70-80. [CrossRef]

32. Kishi, K.; Kirimura, H.; Fujimoto, Y. XPS studies for $\mathrm{NaCl}$ deposited on the Ni(111) surface. Surf. Sci. 1987, 181, 586-595. [CrossRef]

33. Wu, J.; Li, W.; Fortner, J.D. Photoenhanced oxidation of $\mathrm{C}_{60}$ aggregates $\left(\mathrm{nC}_{60}\right)$ by free chlorine in water. Environ. Sci. Nano 2017, 4, 117-126. [CrossRef]

34. Mo, X.; López, D.E.; Suwannakarn, K.; Liu, Y.; Lotero, E.; Goodwin, J.G.; Lu, C. Activation and deactivation characteristics of sulfonated carbon catalysts. J. Catal. 2008, 254, 332-338. [CrossRef]

35. Chung, K.H.; Kim, J.; Lee, K.Y. Biodiesel production by transesterification of duck tallow with methanol on alkali catalysts. Biomass Bioenergy 2009, 33, 155-158. [CrossRef]

(C) 2018 by the authors. Licensee MDPI, Basel, Switzerland. This article is an open access article distributed under the terms and conditions of the Creative Commons Attribution (CC BY) license (http://creativecommons.org/licenses/by/4.0/). 